\title{
Erratum to: Macrosegregation During Electroslag Remelting of Alloy 625
}

KYLE FEZI, JEFFREY YANKE, and MATTHEW JOHN M. KRANE

DOI: $10.1007 / \mathrm{s} 11663-015-0326-\mathrm{x}$

(C) The Minerals, Metals \& Materials Society and ASM International 2015

\section{Erratum to: METALL. MATER. TRANS. B DOI 10.1007/s11663-014-0254-1}

THE sentence on lines 110-115 (Another metric has been developed recently by Voller and Vušanović that calculates the volume of the solid ingot which has a macrosegregation level $\left(M_{i}=C_{i} C_{o}\right)$ greater than or equal to $M_{i}$, termed the Cumulative Distribution Function $(\mathrm{CDF})$.) of this article should have a reference number added [23] at the end. Also, the new reference should be added at the end of the references:

23. V.R. Voller and I. Vušanović: Int. J. Heat Mass Transf., 2014, vol. 79, pp. 468-71.

KYLE FEZI, Graduate Research Assistant, and MATTHEW JOHN M. KRANE, Associate Professor, are with Purdue Center for Metal Casting Research, School of Materials Engineering, Purdue University, 701 West Stadium Avenue, West Lafayette, IN 47906. JEFFREY YANKE, Formerly Graduate Research Assistant, the Purdue Center for Metal Casting Research, School of Materials Engineering, Purdue University, is now with the Carpenter Technology Corporation, Reading, PA. Contact e-mail:kfezi@purdue.edu

The online version of the original article can be found under doi: 10.1007/s11663-014-0254-1.

Article published online March 18, 2015. 